\title{
ZPŮSOBY ZDAŇOVÁNÍ DIVIDEND JAKO DŮLEŽITÁ INFORMACE PRO ROZHODOVÁNÍ INVESTORŮ
}

\author{
Ivana Valentová, Jan Široký \\ Klíčová slova: \\ Korporátní daň (CIT), osobní důchodová daň (PIT), vnitřní (ekonomické) dvojí zdanění, \\ Evropská unie, dividendy, akcionáři.
}

Key words:

Corporate tax (CIT), Personal income tax (PIT), Internal (economic) double taxation, European Union, Dividends, Shareholders.

\begin{abstract}
Abstrakt
Samotná nominální (statutární) sazba korporátní daně vypovídá o daňovém zatížení firem velmi málo, je tedy nutné analyzovat další aspekty konstrukce daní. Mezi ty patří i propojení korporátní a osobní daně z př́imů. Stat' si klade za cíl zmapovat vnitřní (ekonomické) dvojí zdanění v zemích EU za pomocí metod analýzy, komparace a syntézy. Dividendová politika státu je totiž rovněž důležitou informací pro investory při zakládání a rozvoji firem.
\end{abstract}

\begin{abstract}
The nominal (statutory) rate of the corporate tax rate reflects the tax burden of companies insufficiently, it is necessary to analyze other aspects of the tax structure. The interconnection of corporate and personal income tax belongs among these aspects. The aim of the paper is to map the internal (economic) double taxation in the EU countries using methods of analysis, comparison and synthesis. Since the dividend policy is also the important information for investors for companies setting up and development.
\end{abstract}

\section{Úvod}

O velikosti daňového zatížení firem př́liš nevypovídá samotná statutární (nominální) sazba korporátní daně (Corporate Income Tax, CIT). Ta se v současnosti ${ }^{1}$ v zemích Evropské unie liší o 25 procentních bodů (Bulharsko, Kypr $10 \%$ versus Malta $35 \%$ ) a pro (alespoň přibližné) stanovení efektivní (skutečné) daňové zátěže firem se používají efektivní sazby firemních daní [Bucovetsky, 2009 nebo Szarowská, 2011], které by měly mít vliv na rozhodování investorů o alokaci svých volných finančních prostředků [zevrubněji Široký, Kvíčalová, Valentová, 2012].

K zintenzivnění snah o nalezení aspektů, které motivují aktivity investorů, dochází zejména pod vlivem rozšiřování Evropské unie [např. Zodrow, 2003 nebo studie ZEW, 2004] a z důvodu upouštění od harmonizace prrímých daní [Cnossen (2003)], kdy je potřeba zavést metodiku, která může testovat prŕpadnou existenci škodlivé daňové konkurence při přetahování „daňových základư“ korporátních daní mezi státy Evropské unie [podrobněji Devereux, Lockwood, Redoano, 2008].

Na základě těchto studií a v souladu se standardní daňovou teorií [např. James, Nobes, 2010] lze považovat změnu v rozhodování investorů $\Delta \mathrm{I}$ umístit kapitál do země jako funkci

\footnotetext{
${ }^{1}$ Stat' vychází z údajů platných k 31. 12. 2011. Zkratky názvů států jsou dle pravidel používaných v EU.
} 
daňových faktorů $\Delta \mathrm{T}$, ostatních ekonomických faktorů $\Delta \mathrm{OE}$ a neekonomických faktorů (včetně byrokratických či korupce), tj. $\triangle \mathrm{OD}$ dle vztahu (1):

$\Delta I=f(\triangle T, \triangle O E, \triangle O D)$.

Mezi běžně analyzované další aspekty korporátních daní $\Delta \mathrm{T}$ (mimo nominální sazby daně), které mohou ovlivňovat investorské aktivity, patří především existence různých metod a doby odpisování, možnost skupinového zdanění, používání různých metod pro oceňování zásob, poskytování rozmanitých investičních pobídek [Sørensen, 2004], kompenzace či přenášení ztrát, výše daně z nemovitostí a z převodu nemovitostí, uplatňování daně z přidané hodnoty na vstupu [komplexně se tyto faktory snaží shrnout materiál Evropské komise, 2004], možnosti odpočtů různých druhů nákladů a další různé daňové úlevy či slevy. V souladu se záměrem stati je do skupiny ostatních daňových faktorů přiřazeno propojení korporátní (CIT) a osobní důchodové daně (PIT).

Metodika stati tedy vychází (viz rovnice (2)) z předpokladu, že významným daňovým faktorem ovlivňujícím investorské rozhodování je interakce mezi korporátní a osobní daní CIT/PIT, které by mělo být svoji důležitostí zařazeno mezi faktory výše nominální sazby korporátní daně NCIT, odpisovou politiku ODP, možností skupinového zdanění firem SKUP, uplatňování ztrát ZTR či investiční pobídky POB:

$\triangle T=f(\triangle N C I T, \triangle O D P, \triangle S K U P, \triangle$ ZTR, $\triangle$ POB, $\triangle$ CIT/PIT $)$.

Cílem stati je definovat jednotlivé systémy integrace CIT a PIT v Evropské unii, seřadit je do jednotlivých skupin a prriřadit jim výhodnost z pohledu potenciálního investora. Stat' vychází z údajů European Tax Handbook [Boeijen-Ostaszewska, 2010, 2011] a vlastního zjišt'ování.

Autoři v textu uvádějí př́́klady zdaňování dividend, je však zřejmé, že modifikované výsledky mohou sloužit ke srovnání zdaňování podílů na zisku obecně.

\section{Materiál}

\subsection{Vnitřní dvojí zdanění a modely propojení korporátní a osobní důchodové daně}

Zatímco mezinárodním dvojím zdaněním se rozumí souběh daňových povinností, uvalených na jeden předmět daně, jež ukládají daňové legislativy dvou různých států, vnitřní (ekonomické) dvojí zdanění nastává v situaci, kdy jsou zisky vyprodukované korporacemi zdaněny dvakrát uvnitř daňového systému jedné země.

Nejprve jsou tedy zdaněny korporátní daní zisky firem a tyto zisky po zdanění, které se následně rozdělují jednotlivým podílníkům (at' už individuálním či korporátním), jsou zdaněny na jejich úrovni opět př́íslušnou daní z př́íjmů.

Dle způsobu integrace korporátní daně ze zisku a následné daně uvalené na př́ijmy akcionářů (podílníků) jsou hraničními systémy: klasický systém dvojího zdanění, kdy neexistuje žádné propojení mezi oběma typy př́jmových daní a zisk je zdaněn dvakrát, a systém vyhýbající se dvojímu zdanění, kdy je zisk zdaněn pouze jednou, a to na úrovni firmy nebo na úrovni př́jemců podílů na zisku.

Popsané extrémní modely jsou vzorovými situacemi uváděnými v literatuře [zevrubněji Široký, 2012], nicméně v praxi až na výjimky neexistují ve své čisté podobě, ale jsou modifikovány různými specifickými odlišnostmi. 


\subsection{Legislativa $k$ vnitřnímu dvojímu zdanění v Evropské unii}

Přestože se Evropská komise snaží o alespoň koordinaci v oblasti př́mých daní, obecný postup pro zamezení dvojího zdanění dividend ve státech EU nebyl zaveden. Žádný $\mathrm{z}$ dosavadních návrhů nebyl přijat a tak $\mathrm{v}$ současnosti používají země EU různé metody eliminace dvojího zdanění dividend. Existuje však patrný trend - vzhledem $\mathrm{k}$ daňové konkurenci jednotlivých států - dvojí zdanění v široké míre eliminovat.

Obecným předpisem, který částečně zamezuje vnitřnímu dvojímu zdanění (mezi mateřskými a dceřinými společnostmi) napříč Unií, je směrnice o společném systému zdanění mateřských a dceřiných společností (The Parent-Subsidiary Directive), ve znění pozdějších předpisů (90/435/EHS) stanovující podmínky pro osvobození dividend mezi mateřskou a dceřinou společností v rámci členských států Unie. Směrnice obsahuje výčet konkrétních názvů daní z prŕíjmů jednotlivých členských států EU a výčet typů obchodních společností, jejichž úpravy se týká.

Podmínky pro daňové osvobození přerozdělovaných dividend určuje následovně: první podmínka pro osvobození ze zdanění dividend na straně korporátního př́ijemce dividend je držba min $10 \%{ }^{2}$ podílu na kapitálu rozdělující společnosti, druhou podmínkou je nepřetržitá doba držby výše uvedeného podílu po dobu min dvou let.

V daňových systémech některých států Unie je v oblasti vnitřního dvojího zdanění zaveden systém, který eliminuje dvojí zdanění v širší míře, než je požadováno směrnicí 90/435/EHS, což však není v rozporu s ustanoveními směrnice. Tato stávající situace umožňuje svojí diferencí i významnou možnost daňové konkurence mezi jednotlivými členskými státy.

\section{Výsledky}

V následujícím textu byly státy EU rozděleny do skupin dle společných znaků a př́stupů k vnitřnímu dvojímu zdanění. Je třeba zdůraznit, že daňové systémy všech států EU jsou odlišné a skupiny států jsou vytvořeny dle obecného systému zdanění, nelze brát ohled na všechny výjimky a osvobození uvnitř těchto daňových systémů. Navíc jsou mezi státy uzavřeny vzájemné daňové smlouvy, které mohou vytvořit rozdílné podmínky pro rezidenty (korporátní i individuální) států stran daných daňových smluv.

Bylo zjištěno, že všechny státy EU lze podle propojení CIT a PIT klasifikovat do šesti skupin: model s klasickým systémem (CIT/PIT KLAS $_{2}$ ), systémy s významnými úlevy pro korporátní i individuální akcionáře (CIT/PIT $\left.\mathrm{ULEV}_{\mathrm{V}}\right)$, systémy s výrazným osvobozením u korporárních př́ijemců dividend (CIT/PIT $\left.\mathrm{KORP}_{\mathrm{P}}\right)$, systémy s možností zápočtu zaplacené daně (CIT/PIT $\left.\mathrm{ZAP}_{\mathrm{Z}}\right)$, systémy vyhýbající se dani (CIT/PIT $\mathrm{VYH}_{\mathrm{V}}$ ) a imputační systémy (plně integrační systém; CIT/PIT IMP).

Platí tedy vztah (3):

$27 x . C I T / P I T=C I T / P I T_{K L A S}+C I T / P I T_{U L E V}+C I T / P I T_{K O R P}+C I T / P I T_{Z A P}+C I T / P I T_{V Y H}+$ CIT/PIT IMP.

\footnotetext{
${ }^{2}$ Platné od 1. 1. 2009, nejprve byla min. hranice pro osvobození stanovena na $20 \%$, od roku 2007 na $15 \%$.
} 
2.1 Osvobození firemních př́ijemců dle výše podílu na kapitálu rozdělující společnosti (mírně modifikované klasické systémy): CIT/PIT KLAS

Klasický systém dvojího zdanění bez větších úprav lze nalézt v České republice, Dánsku, Polsku, Rumunsku a Švédsku. Tyto státy zanesly do svých daňových předpisů úlevu v př́padě tuzemských a zahraničních mezipodnikových dividend pro korporace ve vztahu mateřská a dceřiná společnost. Korporátní př́jemce dividend musí splnit podmínku vlastnictví aspoň $10 \%$ podílu na kapitálu vyplácející společnosti a nepřetržitou dobu držby podílu po dobu aspoň 1 roku v ČR a Švédsku, resp. 2 roky v Polsku a Rumunsku. V Dánsku min. doba držby akcií pro domácí korporace není podmínkou. V př́ípadě nesplnění uvedených podmínek jsou mezipodniková dividenda zdaněna srážkovou daní ve výši $15 \%$ v ČR, $16 \%$ v Rumunsku, $19 \%$ v Polsku, 25\% v Dánsku a jednotnou sazbou daně 26,3 \% ve Švédsku (30\% srážková daň pro nerezidentní korporace). U individuálních př́ijemců dividend zůstává zachováno dvojí zdanění. Pro individuální př́jemce dividend (rezidenty i nerezidenty) je stanovena srážková daň z př́ijmů ve výši $15 \%$ v České republice, 16 \% v Rumunsku, $19 \%$ v Polsku, 28 \% v Dánsku a 30\% plošná sazba ve Švédsku.

\subsection{Systémy s významným osvobozením u firemních i individuálních př́íjemců dividend: CIT/PIT $_{\text {ULEV }}$}

Klasický systém nejvíce modifikovaly a z velké míry tak eliminovaly dopady ekonomického dvojího zdanění pro individuální i korporátní př́ijemce dividend Itálie, Francie, Lucembursko, Německo a Portugalsko. Tyto státy Unie ve svých daňových systémech poskytují možnost uplatnit významné daňové úlevy.

V Itálii je zaveden klasický systém s výjimkou pro domácí korporátní akcionáře, jejichž př́jem z dividend $\mathrm{z}$ domácích i zahraničních zdrojů je z $95 \%$ osvobozen od daně. Dividendové př́ijmy vyplácené nerezidentním korporátním př́ijemcům podléhají konečné $27 \%$ srážkové dani. Úplné osvobození platí pro dividendy placené korporacím ze států EU, pokud drží aspoň $10 \%$ podíl na kapitálu rozdělující společnosti nepřetržitě po dobu 1 roku. Individuální tuzemští akcionáři podléhají srážkové dani $12,5 \%$ z tuzemských i zahraničních zdrojů, i oni však mají nárok na částečné osvobození (49,72 \% dividend je předmětem daně), pokud drží aspoň $2 \%$ hlasovacích práv nebo $5 \%$ podíl na kapitálu společností kótovaných na burze; u ostatních společností je pro osvobození požadován podíl $20 \%$ z hlasovacích práv a $25 \%$ z kapitálu.

Ve Francii mohou být tuzemští korporátní př́jemci dividend $\mathrm{z}$ domácích i zahraničních korporací částečně osvobozeni ${ }^{3}$, pokud vlastní ve dvouletém nepřetržitém období více než $5 \%$ podíl na kapitálu rozdělující korporace. Dividendy vyplácené korporacím členských států EU jsou osvobozeny za podmínek nepřetržité držby $10 \%$ podílu na kapitálu rozdělující společnosti po dobu min. 2 let. Neplatí - li tyto účastnické výjimky, zahrnují domácí korporace př́ijmy z dividend do svého zdanitelného př́ijmu a zahraniční korporace jsou v oblasti př́ijmu z dividend zdaněni $25 \%$ srážkovou daní. V prŕípadě dividend př́ijatých individuálními akcionáři je klasický systém modifikován, pouze $60 \%$ dividend je předmětem progresivní sazby daně. Dividenda, vyplácená nerezidentům, jsou zdaněna srážkovou $25 \%{ }^{4}$ daní.

\footnotetext{
3 Paušální částka ve výši $5 \%$ z čistého zisku představuje daňově neuznatelný náklad, který je přidán ke zdanitelnému zisku a zdaněn hlavní sazbou daně (efektivní sazba 1,72\%). U zahraničních př́iemců dividend je tato částka započitatelná dle daňových smluv.

${ }^{4}$ Individuální příjemci ze zemí EHP zdaňují svůj dividendový př́ijem sníženou 19\% sazbou.
} 
V Lucembursku je klasický systém zmírněn uplatněním 50\% daňové úlevy pro individuální podílníky domácích korporací (které podléhají v tuzemsku korporátní dani). Korporátní akcionáŕi mohou uplatňovat 100\% osvobození, pokud jsou rezidenty Lucemburska, podléhají korporátní dani a drží alespoň $10 \%$ podíl na kapitálu rozdělující korporace nebo se účastní na jejím kapitálu ve výši aspoň 1,2 mil. EUR. Držba podílu musí trvat nepřetržitě po dobu aspoň 12 měsíců. Domácí i zahraniční (korporátní i individuální) př́ijemci dividend podléhají 15\% srážkové dani.

V Německu jsou dividendy pobírané domácími korporacemi osvobozeny od zdanění bez ohledu na výši jejich podílu, doby držby a na zdroj (domácí i zahraniční), nicméně paušální částka ve výši $5 \% \mathrm{z}$ hrubé dividendy je vrácena zpět do zdanitelného prŕíju a představuje neodčitatelný náklad. Dividendy vyplácené rezidentními korporacemi jsou zdaněny srážkovou daní ve výši $25 \%$ u zdroje, ta je plně započitatelná proti daňové povinnosti domácí korporace (př́ijemce). Př́ijem individuálních akcionářu (domácích i zahraničních) je zdaňován 25\% srážkovou daní. Podnikatelé - fyzické osoby zdaňují pouze $60 \%$ obdržených dividend (také pouze $60 \%$ výdajů je daňově uznatelných).

Portugalsko zdaňuje mezikorporátní dividendy 21,5\% srážkovou daní, vyjma dividend domácích nebo obdržených a vyplacených v rámci EU. Srážkovou daní 21,5 \% se zdaňují také individuální př́ijemci dividend. Pokud se domácí individuální akcionáři rozhodnou zdaňovat dividenda zálohově, pak je $50 \%$ dividend přičteno k ostatním př́ijmům a sražená daň započtena na konečnou daňovou povinnost.

\subsection{Systémy s významným osvobozením na straně firemních př́ijemců dividend: CIT/PIT KORP \\ Významným osvobozením na straně tuzemských korporátních př́ijemců dividend modifikovaly klasický systém Belgie, Bulharsko, Irsko, Finsko, Mad'arsko, Slovinsko, Lotyšsko, Recko a Kypr.}

Belgie aplikuje klasický systém modifikovaný významným osvobozením korporátních investorů a snížením sazeb pro individuální investory. Dividendy jsou zdaněny srážkovou $25 \%$ daní. Dividendy obdržené rezidentními korporacemi z účasti v domácích společnostech a korporacích EHP jsou prvně zahrnuty ve zdanitelném př́ijmu, následně je $95 \%$ dividend odečteno. Zbývajících $5 \%$ dividend podléhá dani. Nárok na úplné osvobození vzniká $\mathrm{v}$ prrípadě, že domácí společnost drží $10 \%$ podíl nebo podíl v hodnotě aspoň 2,5 mil. EUR z kapitálu vyplácející společnosti (ta musí podléhat belgické korporátní dani) déle než 1 rok bez přerušení. Dividenda vyplácená zahraničním korporacím podléhají $25 \%$ srážkové dani, žádná daň není uvalena na dividendy vyplácené korporacím ze zemí EU, pokud drží 10\% podíl na kapitálu rozdělující společnosti nepřetržitě po dobu 1 roku.

V Bulharsku tuzemští korporátní př́ijemci nedaní své př́ijmy z dividend z domácích ani zahraničních zdrojů bez jakýchkoliv podmínek. Zahraniční korporátní př́jemci zdaňují dividendové příjmy $5 \%$ sazbou daně, opět vyjma př́ijemců ze zemí EHP.

Irsko osvobozuje od korporátní daně dividendy vyplácené mezi tuzemskými korporacemi, sazba daně $20 \%$ platí pro zahraniční dividendy, vyjma dividend ze států EU nebo dle smlouvy, $\mathrm{v}$ tomto př́padě platí sazba daně $12,5 \%$. Dividendy vyplácené zahraničním korporacím jsou zdaněny $20 \%$ sazbou. 
Finsko praktikuje klasický systém dvojího zdanění se zabudovaným osvobozením pro dividendy vyplácené mezi tuzemskými korporacemi, standardní sazba daně $26 \%$ platí pouze pro nekótované společnosti s podílem na kapitálu kótované společnosti nižším než $10 \%(75 \%$ část $\mathrm{z}$ dividend je zdaňováno a $25 \%$ část je osvobozena ${ }^{5}$ ). Osvobození za stejných podmínek platí také na dividendy vyplácené korporacemi ze zemí EU. Pro nerezidentní korporátní př́jemce dividend je stanovena srážková daň ve výši $28 \%$.

Mad'arsko uplatňuje částečný integrační systém. Dividendy vyplácené domácím i zahraničním korporacím jsou osvobozeny od dalšího zdanění. Zahraniční dividendy jsou také osvobozeny od daně. Zdanění podléhají pouze dividendy v držení individuálních podílníků.

Ve Slovinsku jsou domácí interkorporátní dividendy osvobozena od daně, pokud rozdělující korporace podléhá korporátní dani (paušální částka ve výši $5 \%$ z přijatých dividend je vyňata z osvobození), osvobození platí i pro dividendy rozdělujících korporací z EU. Dividendy vyplácené korporacím do jiných států EU musí splnit pro osvobození podmínku držby $10 \%$ podílu na kapitálu po dobu dvou let nepřetržitě. V ostatních případech Slovinsko uplatňuje na dividendy $15 \%$ srážkovou daň.

V Lotyšsku domácí mezikorporátní dividendy nejsou předmětem daně ${ }^{6}$, dividendy obdržené od nerezidentních korporací jsou zdaňovány, pokud rezident vlastní méně než $25 \%$ podíl na kapitálu či hlasovacích právech rozdělující společnosti - nerezidenta, vyjma členských států EU. Dividendy distribuované zahraničním korporacím jsou zdaněny $10 \%$ srážkovou daní vyjma korporátních př́ijemců ze států EHP.

V Řecku jsou dividendy vyplácené domácími firmami ze zisku po zdanění zdaněny srážkovou daní $21 \%$, která je platná pro domácí i zahraniční př́ijemce (individuální i korporátní). Osvobozeny jsou mezikorporátní dividendy v rámci EU (za podmínky dvouleté nepřetržité držby $10 \%$ podílu na kapitálu).

Kypr ve svém klasickém daňovém systému zavedl osvobození mezikorporátních dividend pro domácí i zahraniční dividendy.

Ve všech těchto státech není zavedeno osvobození pro rezidentní individuální akcionáře, jejichž dividendové př́ijmy z domácích i zahraničních zdrojů jsou zdaněny srážkovou daní (Bulharsko $5 \%$, Belgie $25 \%$, Finsko $28 \%$, Kypr $15 \%$, Lotyšsko $10 \%$, Mad'arsko $16 \%$, Řecko $25 \%$, Slovinsko 20\%) nebo př́slušnou sazbou daně (Irsko 20\%).

\subsection{Systémy s možností zápočtu zaplacené daně či daňové úlevy: CIT/PIT ZAP}

Klasické systémy uplatňují také Litva, Rakousko, Španělsko a Nizozemí. Eliminace dvojího zdanění spočívá především v možnosti zápočtu již zaplacené daně.

Litva uplatňuje pro dividendy rozdělované individuálním akcionár̆ưm klasický systém. Individuální akcionáŕi jsou zdaňováni $20 \%$ srážkovou daní, která se započítává na konečnou daňovou povinnost poplatníka. Pro mezikorporátní dividendy je dvojí zdanění prakticky eliminováno - tuzemská mezikorporátní dividenda jsou předmětem $15 \%$ daně z př́ijmů firem (srážka u zdroje), avšak přijímající společnost může započíst sraženou daň oproti svojí daňové

\footnotetext{
${ }^{5}$ Efektivní sazba daně je tedy $19,5 \%$.

${ }^{6}$ Nicméně jestliže rozdělující společnost má nárok na daňové úlevy $\mathrm{v}$ jedné ze speciálních ekonomických zón, obdržená dividenda jsou zdaňována.
} 
povinnosti. Srážková daň není realizována, jestliže firma př́jemce drží více než $10 \%$ hlasovacích práv v rozdělující společnosti po dobu nejméně 12 měsíců.

Daňový systém Nizozemí je založen na klasickém systému, mezikorporátní dividendové př́ijmy jsou principiálně zdaněny $15 \%$ srážkovou daní, která je započitatelná proti korporátní daňové povinnosti. Daň z dividend rozdělovaných tuzemskými i zahraničními korporacemi není sražena $v$ prŕípadě, že př́jemce dividend je rezidentní korporace, anebo nerezident se stálou provozovnou v Nizozemí. Ostatní zahraniční korporátní př́ijemci dividend jsou zdaněni konečnou $15 \%$ srážkovou daní. Individuální akcionáři s alespoň $5 \%$ podílem na kapitálu společnosti jsou zdaňováni nižší $25 \%$ paušální sazbou daně, která je plně započitatelná proti daňové povinnosti poplatníka.

V Rakousku jsou dividendy individuálních př́jemců i dividendy z portfolia korporátních př́ijemců zdaňovány $25 \%$ srážkovou daní. Pro individuální akcionáře je tato daň konečná, pokud je méně výhodná než polovina efektivní sazby na poplatníkův ostatní př́ijem, může poplatník do 5 let podat žádost o aplikaci mírnější sazby. U korporátních akcionářů je daň započitatelná na jejich konečnou daňovou povinnost nebo navrácena na základě žádosti.

Španělsko praktikuje klasický systém dvojího zdanění, při kterém je korporátní př́jem nejprve zdaněn v rukou korporací základní 30\% sazbou daně, a dividendy jsou následně zdaněny v rukou akcionářů 19\% sazbou. Kromě toho dividendy odvozené korporátními akcionáři mohou být oprávněny pro účastnickou výjimku, úplné osvobození v př́ípadě, že firma drží aspoň 5\% kapitálu po dobu 1 roku. Jestliže tato úleva není využita, může být 50 \% daně $\mathrm{z}$ př́ijmů korporací započteno vůči finální daňové povinnosti př́ijemce. Tuzemští individuální akcionáři zahrnují př́ijmy z domácích i zahraničních dividend (před srážkovou daní) mezi své zdanitelné př́íjmy, kdy dividendy jsou osvobozeny do výše 1500 EUR/rok a dividendy nad limit jsou zdaněny $19 \%$ sníženou sazbou daně. Tento způsob zdanění se uplatňuje i na dividendy vyplácené individuálním nerezidentům, jak ilustruje Tab. 1.

Tabulka 1: Zdanění dividendových podílů korporátních akcionářů ve Španělsku ${ }^{7}$ (v tis. EUR)

\begin{tabular}{|l|r|}
\hline Př́ijem korporací před zdaněním & 100 \\
\hline Daň z př́íju korporací (sazba 30 \%) & $0,3 \times 100=30$ \\
\hline Rozdělitelný zisk & $100-30=70$ \\
\hline Srážková daň (sazba 19\%) & $0,19 \times 70=13,3$ \\
\hline Čistý dividendový př́ijem & $70-13,3=56,7$ \\
\hline Navýšení o srážkovou daň (hrubé dividendy) & $56,7+13,3=70$ \\
\hline Korporátní daň (30\%) & $0,3 \times 70=21$ \\
\hline Daňová sleva (50\% z 21) & $0,5 \times 21=10,5$ \\
\hline Srážková daň & 13,3 \\
\hline Daňová povinnost & 2,8 \\
\hline Čistý př́ijem z dividend & $70-2,8=67,2$ \\
\hline
\end{tabular}

\footnotetext{
${ }^{7}$ Př́́klad uvedený v Tab. 1 je převzat z Boeijen-Ostaszewska (2011), s. 777.
} 


\subsection{Imputační systémy: CIT/PIT IMP}

Imputační systém je uplatňován na Maltě, kde jsou korporace i jednotlivci zdaňováni stejným způsobem. Dividendy vyplácené domácími společnostmi (rezidentům a nerezidentům) nesou daňový dobropis, úměrný $\mathrm{k}$ dani ze zisků placených rozdělující společností. Akcionáři jsou zdaňováni z částky hrubých dividend př́slušnou daňovou sazbou, mohou však odečíst zaplacenou daň (jako slevu na dani) oproti své celkové daňové povinnosti (rezidenti i nerezidenti). Zisk rozdělovaný z nezdaněného př́ijmu je v rukou rezidentů - individuálních podílníků zdaněn $15 \%$ srážkovou daní, v rámci daňového přiznání jsou dividendy zdaněny běžnou sazbou a přeplatek nad úroveň srážkové daně může být navrácen. Nerezidenti tuto daň neplatí.

Velká Británie uplatňuje částečný imputační systém spočívající v daňovém zápočtu ve výši 1/9 vyplacené dividendy, což je specifické v celé Evropské unii [zevrubněji Nerudová, 2011]. Velká Británie zavádí od roku 2009 (Finance Act 2009) osvobození od daně pro př́ijemce střední a velké podniky bez ohledu na zemi původu rozdělující společnosti. Zákon stanovuje seznam tříd společností, kterým náleží osvobození (např. distribuce ovládaných společností); stanovuje také výčet př́padů vyloučených z osvobození. Malé podniky (vymezení dle doporučení Komise 2003/361) jsou v pozici př́ijemců dividend osvobozeny od daně, jestliže rozdělující společnost je rezidentem Velké Británie nebo státu, se kterým má VB uzavřenu smlouvu. Obecně platí, že imputační kredit nemohou uplatnit nerezidenti; tyto vztahy se dále řídí dle mezinárodních daňových smluv, často bývá stanoven minimální podíl na kapitálu jako podíl navrácení kreditu, na který je uplatněna srážková daň dle smluv. Specifičnost imputačního systému v př́ípadě korporátních př́ijemců ilustruje Tab. 2.

Tabulka 2: Zdanění př́ijmů z dividend u korporátních př́ijemců ve Velké Británii ${ }^{8}$ imputačním systémem (v tis. GBD).

\begin{tabular}{|c|c|}
\hline \multicolumn{2}{|c|}{ Rozdělující společnost: } \\
\hline Př́íjem korporací před zdaněním & 1500 \\
\hline Daň z př́ijmu korporací (sazba 28 \%) & $0,28 \times 1500=420$ \\
\hline Rozdělitelný zisk & $1500-420=1080$ \\
\hline Imputační kredit (1/9) & $1 / 9 \times 1080=120$ \\
\hline Hrubý dividendový prŕíjem & $1080+120=1200$ \\
\hline \multicolumn{2}{|c|}{ Akcionář: } \\
\hline Hrubý dividendový př́ijem & 1200 \\
\hline Daň z př́ijmu korporací (sazba 28 \%) & $0,28 \times 1200=336$ \\
\hline Imputační kredit & 120 \\
\hline Daňová povinnost & $336-120=216$ \\
\hline Čistý př́ijem $\mathrm{z}$ dividend & $1200-216=984$ \\
\hline
\end{tabular}

Domácí dividendy obdržené individuálními tuzemskými akcionáři jsou zdanitelné sníženou sazbou (díky imputačnímu kreditu ve výši 1/9, viz tabulka č. 3). Základní sazba daně je ve výši $28 \%$, snižuje se o imputační kredit, tj. o 1/9 základu daně. Snížená sazba daně ve výši

\footnotetext{
${ }^{8}$ Př́klad uvedený v tabulce je zpracován na základě Boeijen-Ostaszewska (2011), s. 903 a Nerudová (2011), s. 305.
} 
$18 \%$ je uvalena na dividendy individuálních poplatníků, pokud jejich celkový roční př́jem nepřesáhne 35000 GBP. Imputační systém aplikovaný na individuální prŕíjemce dividend je znázorněn v Tab. 3.

Tabulka 3: Zdanění př́ímů $\mathrm{z}$ dividend $\mathrm{u}$ individuálních př́ijemců ve Velké Britániii ${ }^{9}$ imputačním systémem (v tis. GBP).

\begin{tabular}{|l|r|}
\hline Dividendový př́jem & 10000 \\
\hline Imputační kredit (1/9) & $10000 / 9=1111$ \\
\hline Základ daně & $10000-1111=8889$ \\
\hline Daň z př́ímů (28 \%) & $0,28 \times 8889=2489$ \\
\hline Odpočet kreditu & -1111 \\
\hline Daň k zaplacení & $2489-1111=1378$ \\
\hline Čistý př́́jem z dividend & $10000-1378=8622$ \\
\hline
\end{tabular}

\subsection{Systémy vyhýbající se dvojímu zdanění dividend: CIT/PIT}

Systémy vyhýbající se dvojímu zdanění jsou založeny na principu zdanění zisků pouze jednou, a to bud' na úrovni firmy, nebo na úrovni jednotlivce.

V Estonsku firmy nejsou subjektem korporátní daně, zadržené zisky dani nepodléhají. Distribuční dani (ve výši $21 \%$ ) podléhá pouze rozdělený zisk. Osvobození od distribuční daně je uplatněno $v$ prrípadě, že mateřská korporace vlastní aspoň $10 \%$ podíl na kapitálu či hlasovacích právech dceřiné rozdělující korporaci a zároveň rozdělující společnost je rezidentem Estonska nebo jiné země EHP či Švýcarska a je osobou povinnou k dani. Akcionáŕi př́ijmy z dividend domácích korporací nezahrnují do svých zdanitelných př́ijmů, distribuční daň placená rozdělující korporací je daní konečnou. Dividendy plynoucí individuálním akcionářum od netuzemských korporací jsou také osvobozeny, pokud z rozdělovaných zisků od zahraničních korporací již byla zaplacena korporátní daň v př́islušné zemi.

Slovensko uplatňuje jednoduchý daňový systém spočívající ve zdanění zisku na úrovni vyplácející společností (19\% sazba), kdy takto zdaněné rozdělené zisky nepodléhají dani v rukou firemních ani individuálních prŕíjemců dividend (rozdělení zisku odvozeného od 1. 1.2004).

\section{Závěr}

Dosažené výsledky dokumentují značnou rozmanitost systémů propojení CIT a PIT ve státech Evropské unie, což je ilustrováno Tab. 3. a přehledem (4), což je modifikovaným vztah (3).

\footnotetext{
${ }^{9}$ Př́klad uvedený v tabulce je převzat z Nerudová (2011), s. 302.
} 
Tabulka 4: Rozdělení systémů propojení CIT a PIT v zemích EU ${ }^{10}$

\begin{tabular}{|c|c|c|c|c|c|}
\hline CIT/PIT $_{\text {KLAS }}$ & CIT/PIT $_{\text {ULEV }}$ & CIT/PIT KORP & $\mathbf{C I T}_{\mathbf{P I T}}^{\mathrm{ZAP}}$ & CIT/PIT $_{\text {VYH }}$ & CIT/PIT $_{\text {IMP }}$ \\
\hline $\mathrm{CZ}$ & IT & $\mathrm{BE}$ & LT & $\mathrm{EE}$ & MT \\
\hline DK & FR & $\mathrm{BG}$ & $\mathrm{AT}$ & SK & UK \\
\hline PL & LU & IE & ES & & \\
\hline RO & $\mathrm{DE}$ & FI & NL & & \\
\hline SE & PT & $\mathrm{HU}$ & & & \\
\hline & & SI & & & \\
\hline & & LV & & & \\
\hline & & EL & & & \\
\hline & & $\mathrm{CY}$ & & & \\
\hline
\end{tabular}

Tato různorodost může přispívat $\mathrm{k}$ volbě investorů při alokaci volných finančních zdrojů. Oblast vnitřního zdanění by měla být zahrnována do důležitých daňových faktorů, resp. jejich změn $\Delta \mathrm{T}$ relevantních pro investory a měla by být přiřazována svým významem $\mathrm{k}$ aspektům, které se obvykle testují: $\Delta$ NCIT, $\Delta$ ODP, $\Delta$ SKUP, $\Delta$ ZTR, $\Delta$ POB, jak bylo uvedeno v metodice stati. Z pohled výhodnosti systémů propojenosti CI a PIT je samozřejmě optimální systém CIT/PIT ${ }_{V Y H}$, u hodnocení dalších integrací je nutné při konkrétním výpočtu efektivnost zohledňovat př́slušné sazby v konkrétních zemích a stupeň efektivní daňové úspory.

Je nutné rovněž zmínit, že přijatý model vnitřního zdanění může ovlivňovat př́ijmy veřejných rozpočti̊. Zatímco v posledních letech se vzájemné daňové relace CIT/PIT takřka neměnily [Valentová, 2009 na základě šetření z Kesti, 2007-2009], ekonomická krize se dotýká i této oblasti, což ukazuje př́pad Řecka, které opětovně zavedlo $25 \%$ srážkovou daň na dividendy. Dají se tedy očekávat posuny ve výši vnitřního zdanění v budoucím období.

Způsob propojení CIT a PIT je významný rovněž pro velikost tzv. daňových klínů, které jsou definovány jako rozdíl mezi požadovanou mírou výnosnosti firemního kapitálu před zdaněním a čistým osobním důchodem (výnosem) investora po zdanění, a to jak korporátní daní CIT, tak i osobní důchodovou daní PIT [blíže Vítek, 2008]. Podle tohoto konceptu zajímá investora, resp. akcionáře čistý př́ijem po zdanění oběma typy důchodových daní.

Samotná nominální sazba korporátní daně je tedy nedostatečnou a nekomplexní informací pro investory, což je možné dokumentovat Grafem 1, kdy země EU s nejvyšší sazbou CIT má z hlediska investora nejvýhodnější propojení CIT a PIT.

\footnotetext{
${ }^{10}$ Zdroj: Vlastní zpracování autorů.
} 
Graf 1: Propojení CIT/PIT a statutární sazba korporátní daně ${ }^{11}$

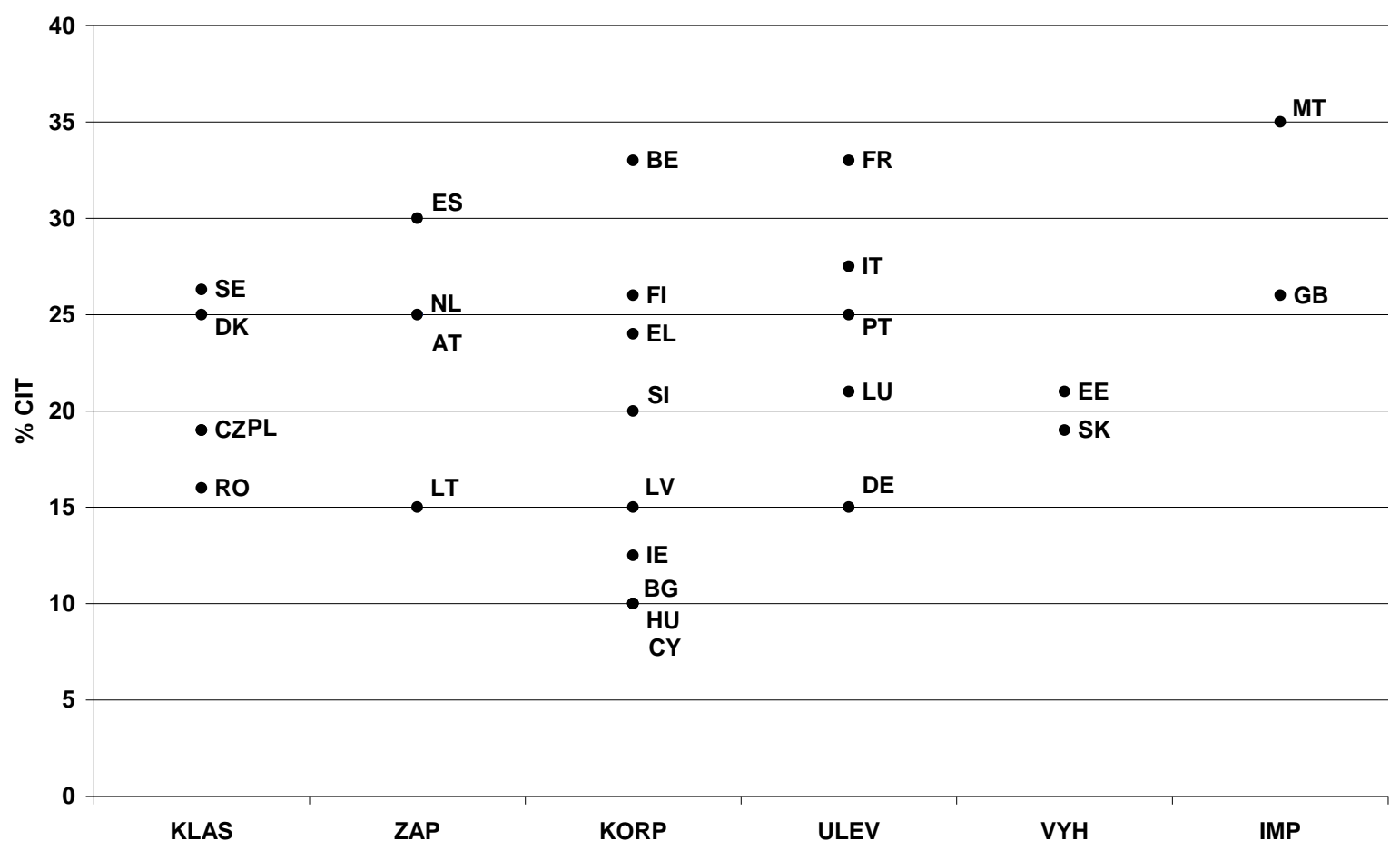

Zatímco fungování jednotného vnitřního trhu Evropské unie $\mathrm{z}$ „daňového“ pohledu nadnárodních společností je ošetřeno směrnicí o fúzích, směrnicí o společném systému zdanění mateřských a dceřiných společností a směrnicí o zdaňování úroků a licenčních poplatků, vnitřní dvojí zdanění v jednotlivých státech není jednotně legislativně upraveno. Přesto je důležitou charakteristikou daňového systému konkrétní země, která zajímá investory.

Zatímco fungování jednotného vnitřního trhu Evropské unie $\mathrm{z}$ „daňového“ pohledu nadnárodních společností je ošetřeno směrnicí o fúzích, směrnicí o společném systému zdanění mateřských a dceřiných společností a směrnicí o zdaňování úroků a licenčních poplatků, vnitřní dvojí zdanění v jednotlivých státech není jednotně legislativně upraveno. Přesto je důležitou charakteristikou daňového systému konkrétní země, která zajímá investory.

\section{Literatura:}

[1] BOEIJEN-OSTASZEWSKA, O. (Ed.) European Tax Handbook 2010. Amsterdam: IBFD, 2010. 920 s. ISBN 978-90-8722-076-1.

[2] BOEIJEN-OSTASZEWSKA, O. (Ed.) European Tax Handbook 2011. Amsterdam: IBFD, 2011. 930 s. ISBN 978-90-8722-093-8.

[3] BUCOVETSKY, S. An Index of Capital Tax Competition. International Tax and Public Finance. XVI, 2009, No. 6, pp. 727-752. ISSN 0927-5940.

[4] CNOSSEN, S. How Much Tax Coordination in the European Union? International Tax and Public Finance. Vol. 10, 2003, No. 6.

[5] DEVEREUX, M., LOCKWOOD, B., REDOANO, M. Do countries compete over Corporate Tax Rates? Journal of Public Economics. Vol. 44, 2008, pp. 1210-1235.

\footnotetext{
${ }^{11}$ Zdroj: Vlastní zpracování autorů.
} 
[6] EUROPEAN COMMISSION. Measuring the Effective Levels of Company Taxation in the New Member States: A quantitative Analysis. Working Papers, 2004, No. 7. 55 s. ISBN 92-894-7960-4.

[7] JAMES, S., NOBES, Ch. The Economics of Taxation. Principles, Policy and Practice. $10^{\text {th }}$ Edition. London: Fiscal Publication, 2010. 324 s. ISBN 978-1906201-13-5.

[8] KESTI, J. (Ed.) European Tax Handbook 2007. Amsterdam: IBDF, 2007. 844 s. ISBN 978-90-8722-015-0.

[9] KESTI, J. (Ed.) European Tax Handbook 2008. Amsterdam: IBDF, 2008. 862 s. ISBN 978-90-8722-031-0.

[10] KESTI, J. (Ed.) European Tax Handbook 2009. Amsterdam: IBFD, 2009. 892 s. ISBN 978-90-8722-076-1.

[11] NERUDOVÁ, D. Harmonizace daňových systémů zemí Evropské unie. 3. vyd. Praha: Wolters Kluwer ČR, 2011. 320 s. ISBN 978-80-7357-695-0.

[12] SØRENSEN, P. (Ed.) Measuring the Tax Burden on Capital and Labor. Cambridge: MIT Press, 2004. 358 s. ISBN 0-262-19503-8.

[13] SZAROWSKÁ, I. Jak vysoké je korporátní daňové zatížení? Acta Academica Karviniensia. 2011, č. 2, ISSN 1212-415X, s. 196-207.

[14] ŠIROKÝ, J. Daně v Evropské unii. Praha: Linde Praha, 2012. 400 s. ISBN 978-807201-881-9.

[15] ŠIROKÝ, J., KVÍČALOVÁ, J., VALENTOVÁ, I. Identification of Causes Differences in Statutory and Effective Rates of Corporate Taxes. Acta Universitatis Agriculturae et Silviculturae Mendelianae Brunensis. LX, 52, Number 2, 2012. s. 391 - 397.

[16] VALENTOVÁ, I. Propojení korporátní a osobní důchodové daně v zemích EU. In Zborník príspevkov z XI. Ročníka medzinárodnej vedeckej konferencie pod názvom Finance a riziko. Bratislava: Ekonóm, 2009, s. 450-458. ISBN 978-80-225-2867-2.

[17] VÍTEK, L. Ekonomická analýza zdanění př́imů. Praha: IREAS, 2008. 312 s. ISBN 97880-86684-50-5.

[18] ZEW. Company Taxation in the New EU Member States. 2nd Edition. Frankfurt: ZEW, 2004. 49 s. ISBN neuvedeno.

[19] ZODROW, G. R. Tax Competition and Tax harmonization in the European Union. International Tax and Public Finance. Vol. 13, 2006, No. 2/3.

\section{JEL H25, H22}

\section{Ing. Ivana Valentová}

Odborný asistent Ústav ekonomie

Moravská vysoká škola Olomouc, o.p.s.

Jeremenkova 1142/42, 77200 Olomouc

Tel.: 587332343

ivana.valentova@mvso.cz

prof. Ing. Jan Široký, CSc.

profesor Katedra účetnictví

Ekonomická fakulta

VŠB - Technická univerzita Ostrava

Sokolská 33, 70121 Ostrava

Tel.: 597322222

jan.siroky@vsb.cz 